\title{
Superparamagnetic Iron Oxide as an Efficient Catalyst for the One-Pot, Solvent-Free Synthesis of 5,5-Disubstituted Hexahydropyrimidines and Their Spiro Analogues
}

\author{
Fatemeh Janati, ${ }^{1}$ Majid M. Heravi, ${ }^{2}$ and Ahmad Mirshokraie ${ }^{1}$ \\ ${ }^{1}$ Department of Chemistry, Faculty of Sciences, Payame Noor University, Mashhad 91735-433, Iran \\ ${ }^{2}$ Department of Chemistry, School of Sciences, Alzahra University, Vanak, Tehran, Iran \\ Correspondence should be addressed to Majid M. Heravi; mmh1331@yahoo.com
}

Received 3 September 2012; Revised 27 October 2012; Accepted 10 November 2012

Academic Editor: Saima Q. Memon

Copyright (C) 2013 Fatemeh Janati et al. This is an open access article distributed under the Creative Commons Attribution License, which permits unrestricted use, distribution, and reproduction in any medium, provided the original work is properly cited.

Superparamagnetic $\mathrm{Fe}_{3} \mathrm{O}_{4}$ is shown to act as a very efficient catalyst for the one-pot, three-component synthesis of 5,5-disubstituted hexahydropyrimidines and their spiropiperidines. The catalyst is easily recovered by the use of an external magnet and reused in several reactions without any noticeable loss of activity. The products are obtained in short time and good purity upon separation of the catalyst and evaporation of the volatiles of the reaction mixture.

\section{Introduction}

Hexahydropyrimidines are biologically important. $N, N$ Bisarylhexahydropyrimidines are effective against Ehrlichcarcinoma, LK lymphoma, and Staphylococcus aureus $[1,2]$. The hexahydropyrimidine skeleton occurs in alkaloids such as verbamethine and verbametrine [3]. N-Substituted hexahydropyrimidines are synthetic intermediates for recently discovered spermidine-nitroimidazole drugs for the treatment of A549 lung carcinoma [4] and structural units in new trypanothion ereductase inhibiting ligands for the regulation of oxidative stress in parasite cells [5]. Benzo-fused hexahydropyrimidines or 1,2,3,4-tetrahydroquinazolines are potential R-adrenergic blockers [6] and possess antiplatelet activity [7]. Hexahydropyrimidines are prepared classically by condensations of substituted propane-1,3-diamines with aldehydes and ketones $[8,9]$. Liang and coworkers synthesized this type of compounds using cyclic ketone, amine, and formaldehyde [10]. There are also a few reports in literature describing the synthesis of hexahydropyrimidine derivatives either by using lewis acids and heteropolyacid as catalyst $[11,12]$. In recent years multicomponent reactions (MCR) have become a powerful tool for atom efficient and waste-free synthesis of complex building blocks of "drug-like" motifs $[13,14]$. Generally MCR strategy affords time and cost advantageous, environmentally benign pathways leading to the synthesis of a library of compounds.

In this letter, we report the multicomponent treaction of 1,3-dicarbonyl compounds, amines, and formaldehyde react in one step in the presence of superparamagnetic $\mathrm{Fe}_{3} \mathrm{O}_{4}$ particles at $80^{\circ} \mathrm{C}$ (Scheme 1). The $\mathrm{Fe}_{3} \mathrm{O}_{4}$ NPs were prepared as reported in the literature [15].

Although this important carbon-carbon bond forming reaction has witnessed much recent progress, [16-20] there are still demands for the development of efficient procedures involving inexpensive, recyclable catalytic systems under solvent-free conditions.

\section{Results and Discussion}

Table 1 summarizes the results of the $\mathrm{Fe}_{3} \mathrm{O}_{4}$-catalyzed reaction of 1,3-dicarbonyl compounds, amines, and formaldehyde. Initial experiments were carried out under solvent-free conditions involving the reaction of ethylacetoacetate, aniline and formaldehyde, at $80^{\circ} \mathrm{C}$ catalyzed by $\mathrm{Fe}_{3} \mathrm{O}_{4}$ (Table 1) [12].

A series of catalysts were reported with the standard reaction of ethylacetoacetate, aniline, and formaldehyde. The results are depicted in Table 2. Among various Lewis acids 
TABLE 1: Synthesis of hexahydropyrimidines using 1,3-dicarbonyl compounds/b-keto ester, amines, and formaldehyde.

\begin{tabular}{|c|c|c|c|c|c|c|}
\hline Entry & Products & $\mathrm{R}^{1}$ & $\mathrm{R}^{2}$ & Time (h) & Yield (\%) & $\mathrm{m} . \mathrm{p}\left({ }^{\circ} \mathrm{C}\right)$ \\
\hline 1 & $4 \mathrm{a}$ & OEt & $\mathrm{H}$ & 2.5 & 90 & Brown viscous liquid \\
\hline 2 & $4 \mathrm{~b}$ & OEt & 4-Methyl & 2 & 91 & $"$ \\
\hline 3 & $4 \mathrm{c}$ & $\mathrm{OMe}$ & $\mathrm{H}$ & 3.5 & 87 & \\
\hline 4 & $4 \mathrm{~d}$ & $\mathrm{OMe}$ & 4-Methoxy & 3 & 94 & “ \\
\hline 5 & $4 \mathrm{e}$ & $\mathrm{OMe}$ & 4-Methyl & 3 & 93 & “ \\
\hline 6 & $4 \mathrm{f}$ & $\mathrm{OMe}$ & 3-Methyl & 3 & 86 & “ \\
\hline 7 & $4 g$ & $\mathrm{OMe}$ & 2-Methyl & 3 & 85 & “ \\
\hline 8 & $4 \mathrm{~h}$ & $\mathrm{Ph}$ & $\mathrm{H}$ & 4 & 77 & “ \\
\hline 9 & $4 \mathrm{i}$ & $\mathrm{Ph}$ & 4-Methyl & 4 & 85 & $108-110$ \\
\hline 10 & $4 j$ & O-Allyl & $\mathrm{H}$ & 4.5 & 70 & $78-80$ \\
\hline 11 & $4 \mathrm{k}$ & O-Allyl & 4-Methyl & 4.5 & 73 & Brown viscous liquid \\
\hline 12 & 41 & OEt & 4-nitro & 5 & 75 & “ \\
\hline 13 & $4 \mathrm{~m}$ & OEt & 4-chloro & 3.5 & 83 & “ \\
\hline 14 & $4 n$ & OEt & 4-bromo & 3.5 & 80 & “ \\
\hline
\end{tabular}

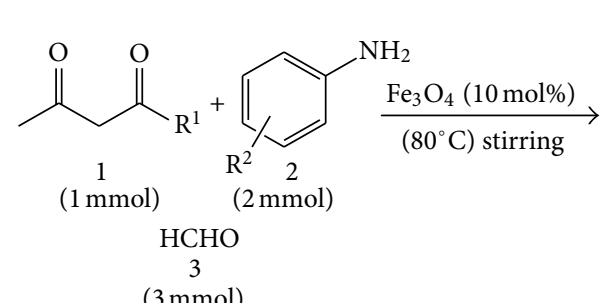

$$
\begin{array}{ll}
\mathrm{R}^{1}=\mathrm{OEt} & \mathrm{R}^{2}=\mathrm{H} \\
\mathrm{R}^{1}=\mathrm{OMe} & \mathrm{R}^{2}=4 \text {-methyl } \\
\mathrm{R}^{1}=\mathrm{Ph} & \mathrm{R}^{2}=3 \text {-methyl } \\
\mathrm{R}^{1}=\mathrm{O} \text {-allyl } & \mathrm{R}^{2}=2 \text {-methyl } \\
& \mathrm{R}^{2}=4 \text {-methoxy }
\end{array}
$$

SCHEme 1: Synthesis of hexahydropyrimindines using 1,3-dicarbony compounds/ $\beta$-keto esters, amines, and formaldehyde.

TABLE 2: Comparison of various types of catalysts used for the synthesis of hexahydropyrimidines with our catalyst.

\begin{tabular}{lccc}
\hline Entry & Catalyst $(5 \mathrm{~mol} \%)$ & Time $(\mathrm{h})$ & Yield (\%) (isolated) \\
\hline 1 & $\mathrm{AlCl}_{3}$ & 6 & 40 \\
2 & $\mathrm{ZnCl}_{2}$ & 6 & 25 \\
3 & $\mathrm{Fe}_{3} \mathrm{O}_{4}$ & 2.5 & 90 \\
4 & $\mathrm{SnCl}_{2}$ & 6 & 30 \\
5 & $\mathrm{AcOH}$ & 6 & 51 \\
6 & $\mathrm{H}_{3} \mathrm{BO}_{3}$ & 6 & 33 \\
7 & $\mathrm{HCl}$ & 6 & - \\
\hline
\end{tabular}

including different metal salts $[13,14], \mathrm{Fe}_{3} \mathrm{O}_{4}$ was found to be the best catalyst (yield 90\%, Table 1, entry 1 ) for the reaction.

In the presence of strong acid like $\mathrm{HCl}$ only trace amount of the product was detected in TLC. This could be due to decomposition of the product in the presence of strong acid. Complete disappearance of the aniline and formation of the product were monitored by TLC. The use of various amounts of the Lewis acid was investigated to optimize the reaction conditions. A catalytic quantity of $\mathrm{Fe}_{3} \mathrm{O}_{4}(10 \mathrm{~mol} \%)$ proved to be effective for complete conversion of the starting materials to the desired product $4 \mathrm{a}$ within $2.5 \mathrm{~h}$ (entry 1 ). The use of lower amounts of the catalyst (down to $2 \mathrm{~mol} \%$ ) prolonged the reaction time up to $5 \mathrm{~h}$ whilst still giving an almost quantitative yield of $4 \mathrm{a}$. Omission of $\mathrm{Fe}_{3} \mathrm{O}_{4}$ from the reaction medium led to formation of only trace quantities of $4 \mathrm{a}$ after several hours indicating the crucial role of the catalyst. Similar reactions of ethylacetoacetate with other amines were conducted under the same conditions affording high yields of the respective products within the same time period. Other aromatic amines bearing electron-releasing groups reacted equally well with various 1,3 -dicarbonyl compounds under the same conditions (entries 2-11). Upon completion of the reactions, the catalyst was recovered from the reaction mixture simply by applying an external permanent magnet and the products were isolated in good purity by removing the volatiles under reduced pressure. Further, the recovered $\mathrm{Fe}_{3} \mathrm{O}_{4}$ was reused successfully in 10 subsequent reactions without significant loss of catalytic performance.

The stoichiometric ratio of $1: 2: 3$ (1,3-dicarbonyl compound: amine: formaldehyde) in the presence of $10 \mathrm{~mol}$ $\%$ of $\mathrm{Fe}_{3} \mathrm{O}_{4}$ in solvent-free condition at $80^{\circ} \mathrm{C}$ was found to be the optimum condition for the maximum yield of hexahydropyrimidines. Under these reaction conditions, 
TABle 3: Synthesis of bis-spiropiperidines using dimedone, aromatic amines, and formaldehyde.

\begin{tabular}{lcccccc}
\hline Entry & $\mathrm{R}^{2}$ & Product & Time $(\mathrm{h})$ & Yield $(\%)$ & m.p $\left({ }^{\circ} \mathrm{C}\right)$ & $196-198$ \\
\hline 1 & 4-Methyl & $5 \mathrm{a}$ & 3 & 89 & 88 & $186-188$ \\
2 & 3-Methyl & $5 \mathrm{~b}$ & 3 & 89 & {$[21]$} \\
3 & 4-Methoxy & $5 \mathrm{c}$ & 3.5 & 73 & $186-188$ & $198-200$ \\
4 & 4-chloro & $5 \mathrm{~d}$ & 5 & {$[21]$} & \\
\hline
\end{tabular}

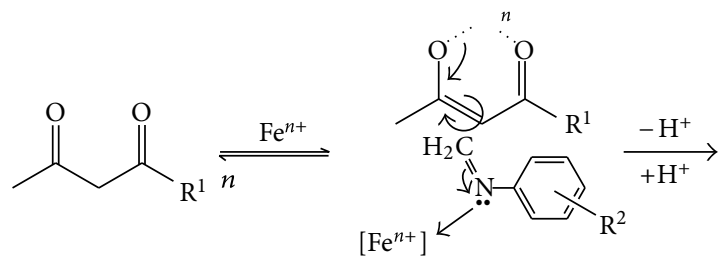<smiles>[R2]C(=O)C(CNc1ccccc1)C(C)=O</smiles>

(A)<smiles>[R][X]c1ccc(CCC(CC(C)=O)(CC(C)C)C([R])=O)cc1</smiles><smiles>[R]C(=O)C(CNc1ccc([R])cc1)(CNc1ccc([R4])cc1)C(C)=O</smiles><smiles>[R4]C(=O)C1(C(C)=O)CN(c2ccc([R4])cc2)CN(c2ccc([R4])cc2)C1</smiles>

Scheme 2: Probable mechanism of hexahydropyrimidine formation

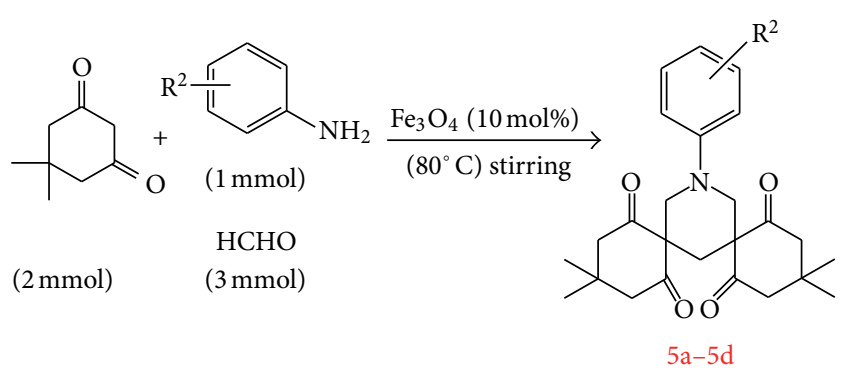

Scheme 3: Synthesis of bis-spiropiperidines using dimedone, aromatic amines, and formaldehyde.

the product $4 \mathrm{a}$ was obtained in a very good yield of $90 \%$ in $2.5 \mathrm{~h}$. After the standardization of the reaction condition, a variety of b-keto esters and 1,3-dicarbonyl compounds like methylacetoacetate, ethylacetoacetate, allylacetoacetate, and 1-benzoyl acetone were used.

A tentative mechanism for the reaction is proposed in Scheme 2. The 1,3-diketone or $\beta$-keto ester undergoes twice $\alpha$-aminomethylation reactions in succession on the same $\alpha$-carbon of carbonyl-catalyzed by $\mathrm{Fe}_{3} \mathrm{O}_{4}$. The condensation of the resulting substituted propane- 1,3-diamine with formaldehyde furnishes the desired spirohexahydropyrimidine. Using Mannich bases instead of $\beta$-keto estersas reactants can also generate the desired products. Here the acidic nature of $\mathrm{Fe}_{3} \mathrm{O}_{4}$ may facilitate both the enolization steps of the 1,3-diketone or $\beta$-ketoestr.

When dimedone was used as 1,3-dicarbonyl compound instead of hexahydropyrimidines, spiro-substituted piperidines were obtained (Scheme 3) with the same methodology. One of the advantages of this methodology is that 3methylaniline also gives the desired product (Table 3, entry 2) which was not possibly using the methodology of Kozlov and Kadutskii [21]. This may happen due to the high reactivity of dimedone. Here maximum yield of the piperidine compound was obtained when dimedone, aromatic amine, and formaldehyde were taken in the ratio of $2: 1: 3$. Probable mechanism for the formation of the bisspiropiperidine is outlined in Scheme 4.

\section{Experimental Section}

3.1. General Procedure for the Synthesis of Hexahydropyrimidines and Their Spiro Analogue. A mixture of $\beta$-keto ester $(1 \mathrm{mmol})$, aniline $(2 \mathrm{mmol})$, formaldehyde $(3 \mathrm{mmol}$, $37-41 \%$ aqueous solution), and a catalytic amount of $\mathrm{Fe}_{3} \mathrm{O}_{4}$ $(10 \mathrm{~mol} \%)$ was stirred at $80^{\circ} \mathrm{C}$ for 2.5 hours. The progress of the reaction was monitored by TLC. Upon completion of the reactions, the catalyst was recovered from the reaction mixture simply by applying an external permanent magnet and the products were purified by column chromate-graphy. All products are known compounds. The identity of the products was confirmed by comparison of their spectroscopic data with literature data. The isolated yields of the products were $70-94 \%$.

3.2. General Procedure for the Synthesis of Spiropiperidines. A mixture of dimedone $(2 \mathrm{mmol})$, aniline $(1 \mathrm{mmol})$, formaldehyde ( $3 \mathrm{mmol}, 37-41 \%$ aqueous solution), and a catalytic amount of $\mathrm{Fe}_{3} \mathrm{O}_{4}(10 \mathrm{~mol} \%)$ in solvent-free condition was 

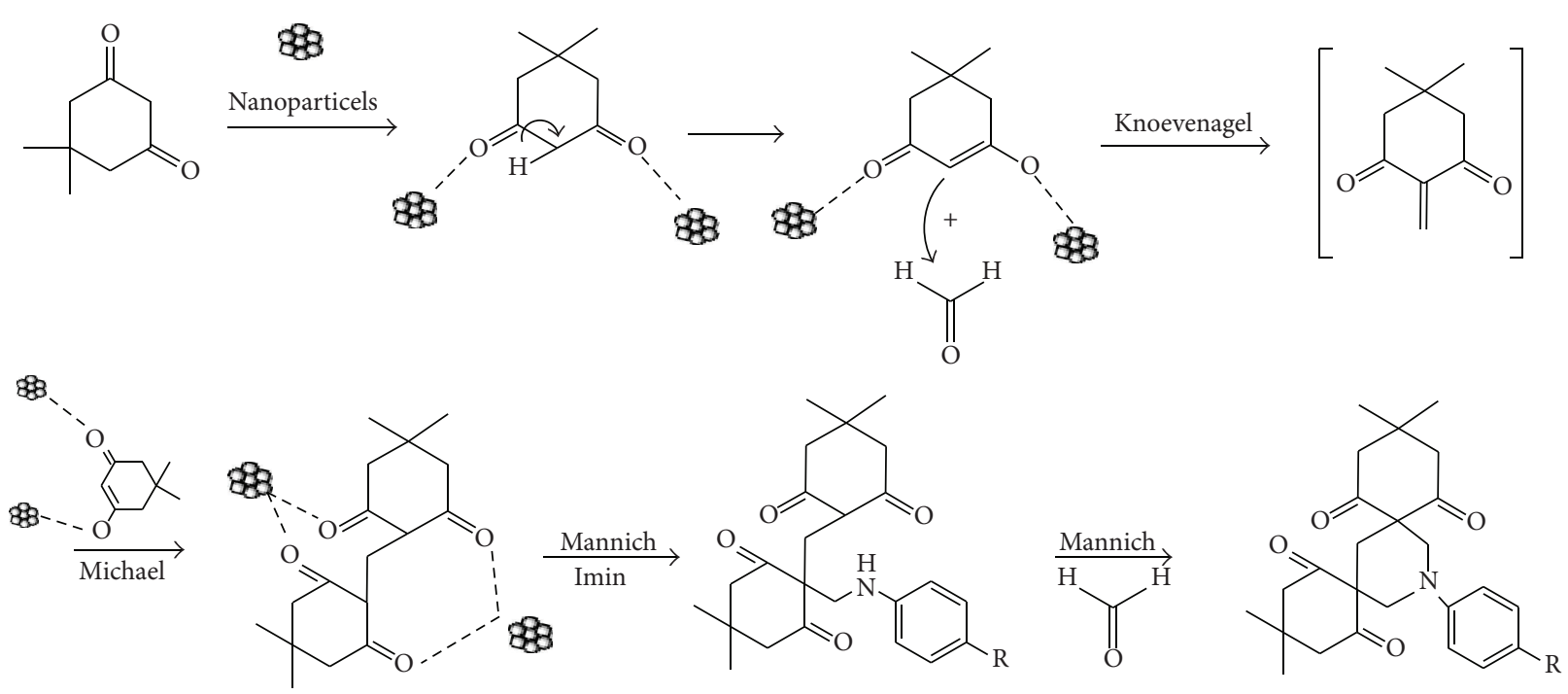

SCHEME 4: Probable mechanism of bis-spiropiperidines formation.

stirred at $80^{\circ} \mathrm{C}$ for 3 hours. The progress of the reaction was monitored by TLC. After the completion of the reaction $\mathrm{Fe}_{3} \mathrm{O}_{4}$ was removed from the reaction mixture by external magnet The solvent was removed under reduced pressure. The crude product mixture was then purified directly by crystallization from etylacetate.

Spectroscopie and analytical data of several compounds have been reported.

\section{The Spectral and Analytical Data of a Few Compounds Reported in Tables 1 and 3}

4.1. 5-Acetyl-1,3-bis-(4-nitrophenyl)-hexahydropyrimidine-5carboxylic Acid Ethyl Ester (41). (Table 1, entry 13) Brown viscous liquid; $v \max (\mathrm{KBr}) / \mathrm{cm}-1$ 3029, 2948, 2825, 2824, $1716,1592,1488,1440,1350,1229,1075,1022,990$, and 815; $1 \mathrm{H} \mathrm{NMR}\left(300 \mathrm{MHz}, \mathrm{CDCl}_{3}\right) \delta \mathrm{H}: 8.15(4 \mathrm{H}, \mathrm{d}, J=8.1 \mathrm{~Hz}$, $\operatorname{ArH}), 7.54(4 \mathrm{H}, \mathrm{d}, J=8.1 \mathrm{~Hz}, \operatorname{ArH}), 4.46(1 \mathrm{H}, \mathrm{d}, J=$ $10.6 \mathrm{~Hz}$, equatorial $\mathrm{N}-\mathrm{CH}-\mathrm{N}), 4.32(1 \mathrm{H}, \mathrm{d}, J=10.6 \mathrm{~Hz}$, axial $\mathrm{N}-\mathrm{CH}-\mathrm{N}), 4.05\left(2 \mathrm{H}, \mathrm{q}, J=7.2 \mathrm{~Hz}, \mathrm{O}-\mathrm{CH}_{2}\right), 3.88(2 \mathrm{H}, \mathrm{d}$, $\left.J=12.3 \mathrm{~Hz}, \mathrm{~N}-\mathrm{CH}_{2}\right), 3.74\left(2 \mathrm{H}, \mathrm{d}, J=12.3 \mathrm{~Hz}, \mathrm{~N}-\mathrm{CH}_{2}\right), 2.26$ $\left(3 \mathrm{H}, \mathrm{s}, \mathrm{CH}_{3}-\mathrm{CO}\right), 1.17\left(3 \mathrm{H}, \mathrm{t}, \mathrm{J}=7.2 \mathrm{~Hz}, \mathrm{O}-\mathrm{CH}_{2}-\mathrm{CH}_{3}\right) ;{ }^{13} \mathrm{C}$ NMR (75 MHz, $\left.\mathrm{CDCl}_{3}\right) \delta \mathrm{C}: 194.2\left(\mathrm{C}, \mathrm{CH}_{3}-\mathrm{CO}-\right), 168.0(\mathrm{C}$, COOEt), 152.6 (C, C aromat), 128.6 (CH, C aromat), 127.76 ( $\mathrm{CH}, \mathrm{C}$ aromat), $116.2\left(\mathrm{CH}, \mathrm{C}\right.$ aromat), $67.3\left(\mathrm{~N}-\mathrm{CH}_{2}-\mathrm{N}\right)$, $62.8\left(\mathrm{CH}_{2}, \mathrm{COO}-\mathrm{CH}_{2}\right), 60.2\left(\mathrm{C}, \mathrm{C}_{5}\right), 54.1\left(\mathrm{CH}_{2}-\mathrm{N}\right), 27.8$ $\left(\mathrm{CH}_{3}-\mathrm{CO}\right), 15.9\left(\mathrm{CH}_{3}, \mathrm{COOCH}_{2} \mathrm{CH}_{3}\right)$; Anal. calcd. for $\mathrm{C}_{21} \mathrm{H}_{22} \mathrm{~N}_{4} \mathrm{O}_{7}$; C: 57.09; H: 4.87; N: 12.61; Found: C: 57.29; H: $4.91 ; \mathrm{N}: 12.57 \%$.

4.2. 5-Acetyl-1,3-bis-(4-chloro-phenyl)-hexahydropyrimidine5-carboxylic Acid Methyl Ester (4m). (Table 1, entry 14) Brown viscous liquid; $v \max (\mathrm{KBr}) / \mathrm{cm}-3010,2944,2848$, 2800, 2701, 1702, 1615, 1459, 1441, 1346, 1209, 1121, 1068, 918 and $8101 \mathrm{H} \mathrm{NMR}\left(300 \mathrm{MHz}, \mathrm{CDCl}_{3}\right) \delta \mathrm{H}: 7.12(4 \mathrm{H}, \mathrm{d}$, $J=8.1 \mathrm{~Hz}, \mathrm{ArH}), 6.85(4 \mathrm{H}, \mathrm{d}, J=8.1 \mathrm{~Hz}, \mathrm{ArH}), 4.33(1 \mathrm{H}, \mathrm{d}$, $J=10.6 \mathrm{~Hz}$, equatorial $\mathrm{N}-\mathrm{CH}-\mathrm{N}), 4.22(1 \mathrm{H}, \mathrm{d}, J=10.6 \mathrm{~Hz}$, axial N-CH-N), 3.35 (4H, s, N-CH $\mathrm{CH}_{2}$, 3.59 (3H, s, OMe), 2.13 $\left(3 \mathrm{H}, \mathrm{s}, \mathrm{CH}_{3}-\mathrm{CO}\right) ; 13 \mathrm{C} \mathrm{NMR}\left(75 \mathrm{MHz}, \mathrm{CDCl}_{3}\right) \delta \mathrm{C}: 200.7(\mathrm{C}$, $\mathrm{CH}_{3}-\mathrm{CO}-$ ), 168.3 (C, COOMe), 146.7 (C, Caromat), 129.5 (C, Caromat), 128.6 ( $\mathrm{CH}$, Caromat), 117.0 ( $\mathrm{CH}$, Caromat), $69.5\left(\mathrm{O}-\mathrm{CH}_{3}\right), 59.6\left(\mathrm{C}, \mathrm{C}_{5}\right), 53.7\left(\mathrm{~N}-\mathrm{CH}_{2}-\mathrm{N}\right), 50.5\left(\mathrm{CH}_{2}-\mathrm{N}\right)$, $29.6\left(\mathrm{CH}_{3}-\mathrm{CO}\right)$, Anal. calcd. for $\mathrm{C}_{20} \mathrm{H}_{20} \mathrm{~N}_{2} \mathrm{O}_{3} \mathrm{Cl}_{2}$; C: 60.62; H: 5.10; N: 7.14; Found: C: 60.57; H: 5.15; N: 7.05\%.

4.3. 5-Acetyl-1,3-di-p-boromo-hexahydropyrimidine-5-carboxylic Acid Ethyl Ester (4n). (Table 2, entry 2) Brown viscous liquid; $v \max (\mathrm{KBr}) / \mathrm{cm}-1$ 2980, 2930, 2863, 2804, $1712,1620,1580,1500,1440,1382,1295,1230,1129,1060$, 1025, 950 and 820; $1 \mathrm{H} \mathrm{NMR}\left(300 \mathrm{MHz}, \mathrm{CDCl}_{3}\right) \delta \mathrm{H}: 7.09$ $(4 \mathrm{H}, \mathrm{d}, J=8.2 \mathrm{~Hz}, \mathrm{ArH}), 7.03(4 \mathrm{H}, \mathrm{d}, J=8.2 \mathrm{~Hz}, \mathrm{ArH})$, $4.47(1 \mathrm{H}, \mathrm{d}, J=10.5 \mathrm{~Hz}$, equatorial $\mathrm{N}-\mathrm{CH}-\mathrm{N}), 4.30(1 \mathrm{H}, \mathrm{d}$, axial N-CH-N), $4.01\left(2 \mathrm{H}, \mathrm{q}, J=7.2 \mathrm{~Hz}, \mathrm{O}-\mathrm{CH}_{2}\right), 3.74(2 \mathrm{H}$, $\left.\mathrm{d}, J=12.3 \mathrm{~Hz}, \mathrm{~N}-\mathrm{CH}_{2}\right), 3.60\left(2 \mathrm{H}, \mathrm{d}, \mathrm{N}-\mathrm{CH}_{2}\right), 2.23(3 \mathrm{H}$, s, $\left.\mathrm{CH}_{3}-\mathrm{CO}\right), 1.21\left(3 \mathrm{H}, \mathrm{t}, J=7.2 \mathrm{~Hz}, \mathrm{O}-\mathrm{CH}_{2}-\mathrm{CH}_{3}\right) ; 13 \mathrm{C}$ $\mathrm{NMR}\left(75 \mathrm{MHz}, \mathrm{CDCl}_{3}\right) \delta \mathrm{C}: 203.0\left(\mathrm{C}, \mathrm{CH}_{3}-\mathrm{CO}-\right), 169.0(\mathrm{C}$, COOEt), 147.2 (C, Caromat), 130.6 (CH, Caromat), 129.76 (CH, Caromat), $118.2\left(\mathrm{CH}\right.$, Caromat), $69.3\left(\mathrm{~N}-\mathrm{CH}_{2}-\mathrm{N}\right)$, $61.8\left(\mathrm{CH}_{2}, \mathrm{COO}-\mathrm{CH}_{2}\right), 59.9\left(\mathrm{C}, \mathrm{C}_{5}\right), 54.1\left(\mathrm{CH}_{2}-\mathrm{N}\right), 26.8$ $\left(\mathrm{CH}_{3}-\mathrm{CO}\right), 13.9\left(\mathrm{CH}_{3}, \mathrm{COOCH}_{2} \mathrm{CH}_{3}\right)$.

4.4. Spectral Data of the Spiropiperidines Tetramethyl-15-(4chlorophenyl)-15-azadispiro [5.1.5.3] Hexadecane-1,5,9,13tetrone (5d). (Table 3, entry 4) m.p.: 198-200 C. IR (KBr): 2959, 2949, 2922, 1732, 1721, 1703, 1689, 1590, 1492, 1250, 1223, 1078, 826, $516 \mathrm{~cm} \_1$. 1H NMR $\left(500 \mathrm{MHz}, \mathrm{CDCl}_{3}\right)$ : $\mathrm{d}=0.96(\mathrm{~s}, 6 \mathrm{H}), 0.97(\mathrm{~s}, 6 \mathrm{H}), 2.46(\mathrm{~s}, 2 \mathrm{H}), 2.61(\mathrm{~d}, J=$ $13.5 \mathrm{~Hz}, 4 \mathrm{H}), 2.79$ (d, $J=13.5 \mathrm{~Hz}, 4 \mathrm{H}), 3.38(\mathrm{~s}, 4 \mathrm{H}), 6.95$ $(\mathrm{d}, J=8.5 \mathrm{~Hz}, 2 \mathrm{H}), 7.30(\mathrm{~d}, J=8.5 \mathrm{~Hz}, 2 \mathrm{H}) .{ }^{13} \mathrm{C} \mathrm{NMR}$ $\left(100 \mathrm{MHz}, \mathrm{CDCl}_{3}\right): \mathrm{d} 28.20,28.50,30.66,32.01,51.05,54.43$, $65.36,113.67,120.21,131.80,150.38,205.76$. 


\section{Acknowledgment}

The authors are thankful to Payame Noor University Research Council for financial support.

\section{References}

[1] S. Groszkowski, L. Korzycka, and W. Bialasiewicz, "1,3Di-(halogenoacyl)-piperimidine and 2-methylpiperimidine derivatives," Polish Journal of Pharmacology and Pharmacy, vol. 25, no. 6, Article ID 116181, pp. 573-577, 1973.

[2] S. Groszkowski, L. Korzycka, and W. Bialasiewicz, "Novel syntheses of hexahydropyrimidines and tetrahydroquinazolines," Chemical Abstracts, vol. 80, 116181r, 1974.

[3] K. Drandarov, A. Guggisberg, and M. Hesse, "Macrocyclic spermine alkaloids from Verbascum: the (E/Z)-Isomeric Pairs (-)-(S)-Verbasitrine/(-)-(S)-Isoverbasitrine and (+)-(S)Verbametrine/(+)-(S)-isoverbametrine: isolation, structure elucidation, and synthesis," Helvetica Chimica Acta, vol. 82, no. 2, pp. 229-237, 1999.

[4] A. Q. Siddiqui, L. Merson-Davies, and P. M. Cullis, "The synthesis of novel polyamine-nitroimidazole conjugates designed to probe the structural specificities of the polyamine uptake system in A549 lung carcinoma cells," Journal of the Chemical Society, no. 22, pp. 3243-3252, 1999.

[5] D. Horvath, "A virtual screening approach applied to the search for trypanothione reductase inhibitors," Journal of Medicinal Chemistry, vol. 40, no. 15, pp. 2412-2423, 1997.

[6] R. Granados, M. Alvarez, N. Valls, and M. Salas, "Synthesis of 1,2,3,4-tetrahydroquinazoline derivatives as potential alphaadrenergic blocking agents," Journal of Heterocyclic Chemistry, vol. 20, no. 5, pp. 1271-1275, 1983.

[7] D. Gravier, J. P. Dupin, F. Casadebaig, G. Hou, M. Boisseau, and H. Bernard, "Synthesis and in vitro study of platelet antiaggregant activity of 1,2,3,4-tetrahydroquinazoline derivatives," European Journal of Medicinal Chemistry, vol. 24, no. 5, pp. 531-535, 1989.

[8] R. F. Evans, "Hydropyrimidines. V. Hexahydropyrimidines. The reaction of aldehydes and ketones with 1,3-diaminopropanes," Australian Journal of Chemistry, vol. 20, no. 8, pp. 1643-1661, 1967.

[9] H. Finch, E. A. Peterson, and S. A. Ballard, "Reactions of acrolein and related compounds. VI. Condensations with amines," Journal of the American Chemical Society, vol. 74, no. 8, pp. 2016-2018, 1952.

[10] H. L. Wei, Z. Y. Yan, Y. N. Niu, G. Q. Li, and Y. M. Liang, "New light on an old story: facile and efficient synthesis of 1,3-diaryl-5-spirohexahydro- pyrimidines via a sixmolecule, three-component mannich-type reaction," The Journal of Organic Chemistry, vol. 72, no. 22, pp. 8600-8603, 2007.

[11] M. M. Heravi, S. Sajadi, H. A. Oskooie, R. HekmatShoar, and F. F. Bamoharram, "Supported preyssler nanoparticles in synthesis of 1,3-diaryl-5-spirohexahydropyrimidines," Journal of the Chinese Chemical Society, vol. 56, pp. 246-250, 2009.

[12] C. Mukhopadhyay, S. Rana, and R. J. Butcher, " $\mathrm{FeCl}_{3}$ catalysed two consecutive aminomethylation at the $\alpha$-position of the $\beta$-dicarbonyl compounds: an easy access to hexahydropyrimidines and its spiro analogues," Tetrahedron Letters, vol. 52, no. 32, pp. 4153-4157, 2011.

[13] R. W. Armstrong, A. P. Combs, P. A. Tempest, S. D. Brown, and T. A. Keating, "Multiple-component condensationstrategies for combinatorial library synthesis," Accounts of Chemical Research, vol. 29, no. 3, pp. 123-131, 1996.

[14] A. Domling and I. Ugi, "Multicomponent reactions with isocyanides," Angewandte Chemie, vol. 39, no. 18, pp. 3168-3210, 2000.

[15] Y. S. Kang, S. Rishbud, J. F. Rabolt, and P. Stroeve, "Synthesis and characterization of nanometer-size $\mathrm{Fe}_{3} \mathrm{O}_{4}$ and $\gamma-\mathrm{Fe}_{2} \mathrm{O}_{3}$ particles," Chemistry of Materials, vol. 8, no. 9, pp. 2209-2210, 1996.

[16] M. M. Mojtahedi, M. S. Abaee, and H. Abbasi, "One-pot, solvent-free synthesis of $\alpha$-aminonitriles under catalysis by magnesium bromide ethyl etherate," Canadian Journal of Chemistry, vol. 84, no. 3, pp. 429-432, 2006.

[17] M. M. Mojtahedi, M. S. Abaee, and H. Abbasi, "Environmentally friendly room temperature Strecker reaction: onepot synthesis of $\alpha$-aminonitriles in ionic liquid," Journal of the Iranian Chemical Society, vol. 3, no. 1, pp. 93-97, 2006.

[18] R. Yousefi, N. Azizi, and M. R. Saidi, "Lithium perchlorate suspend in methylene chloride, a mild, efficient and reusable catalyst for the synthesis of ferrocene aminonitrile derivatives," Journal of Organometallic Chemistry, vol. 690, no. 1, pp. 76-78, 2005.

[19] R. Martínez, D. J. Ramón, and M. Yus, "Catalyst-free multicomponent Strecker reaction in acetonitrile," Tetrahedron Letters, vol. 46, no. 49, pp. 8471-8474, 2005.

[20] A. S. Paraskar and A. Sudalai, "Cu(OTf) ${ }_{2}$ or $\mathrm{Et}_{3} \mathrm{~N}$-catalyzed three-component condensation of aldehydes, amines and cyanides: a high yielding synthesis of $\alpha$-aminonitriles," Tetrahedron Letters, vol. 47, no. 32, pp. 5759-5762, 2006.

[21] N. G. Kozlov and A. P. Kadutskii, "A novel three-component reaction of anilines, formaldehyde and dimedone: simple synthesis of spirosubstituted piperidines," Tetrahedron Letters, vol. 49, no. 29-30, pp. 4560-4562, 2008. 

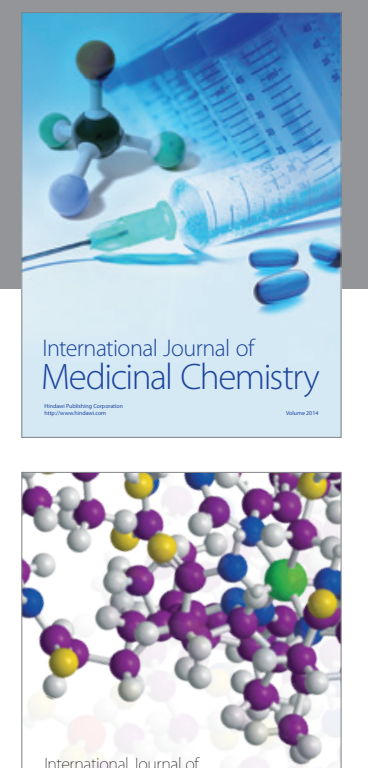

\section{Carbohydrate} Chemistry

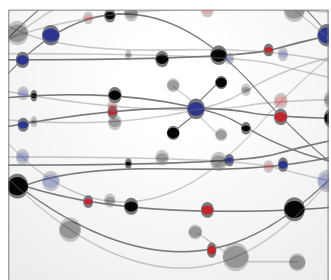

The Scientific World Journal
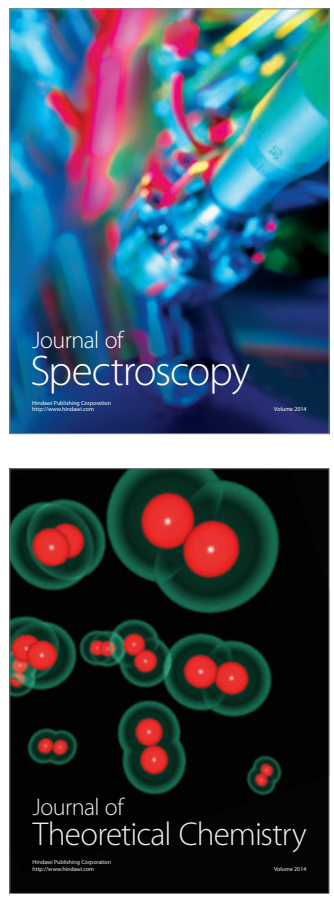
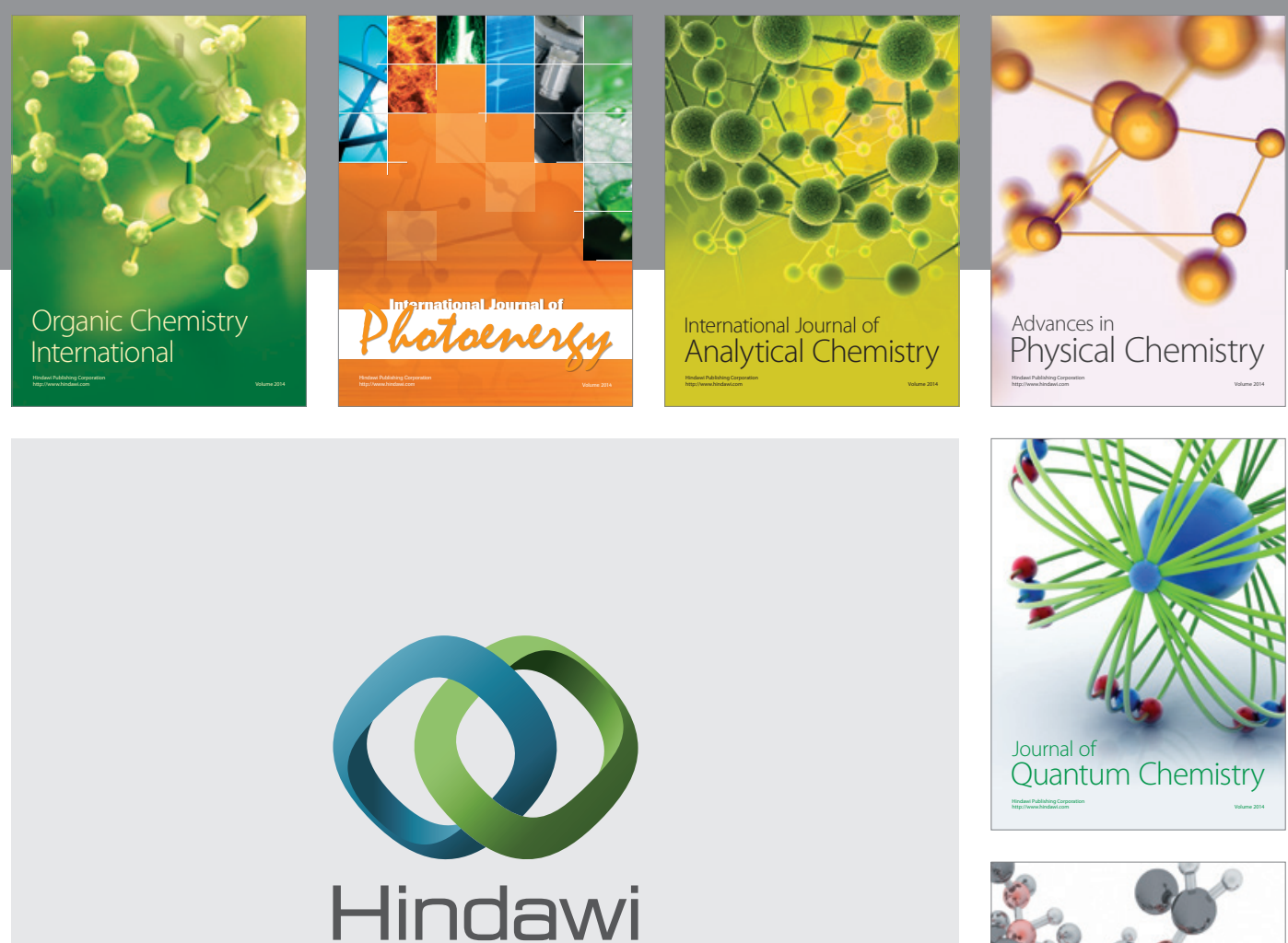

Submit your manuscripts at

http://www.hindawi.com

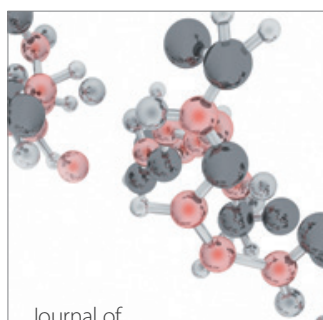

Analytical Methods

in Chemistry

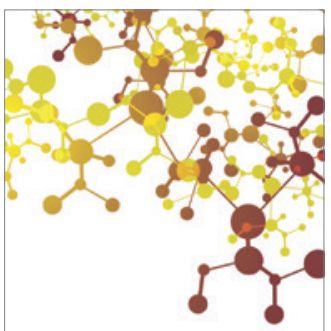

Journal of

Applied Chemistry

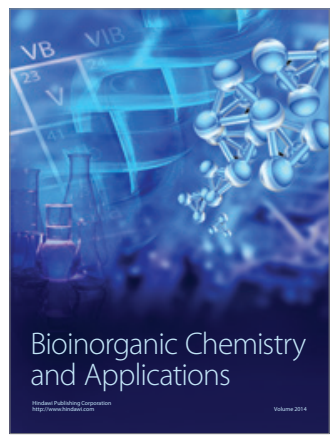

Inorganic Chemistry
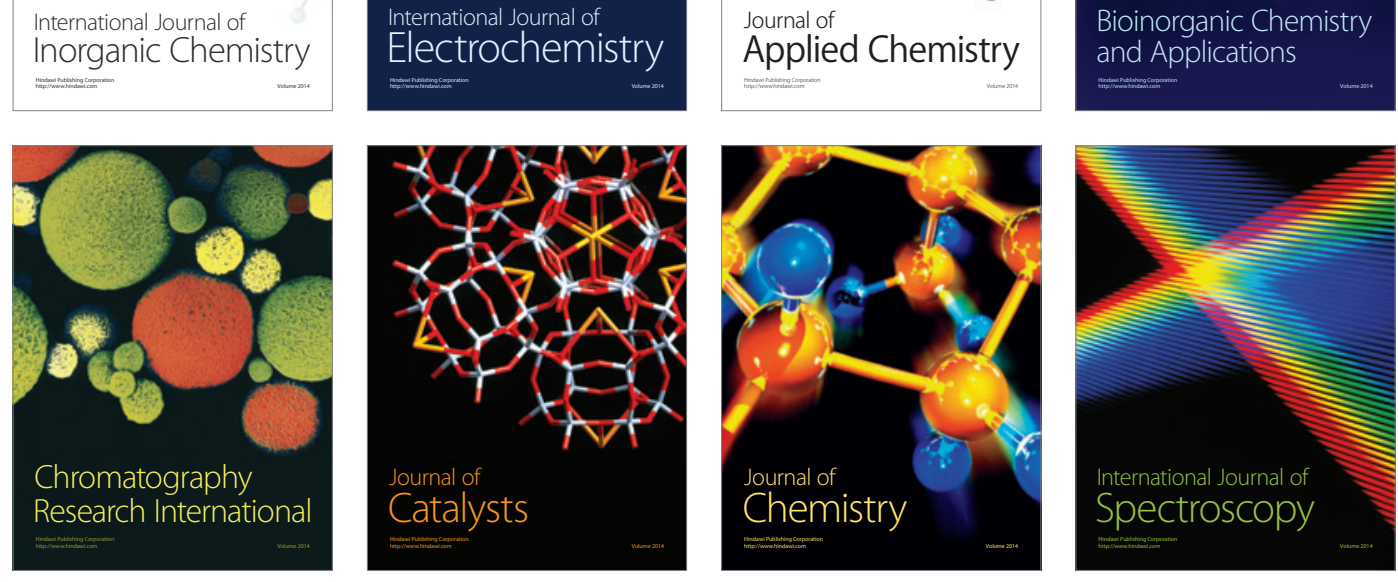